\title{
Хірургічне лікування хворих з перфорацією стравоходу, ускладненою гострим гнійним медіастинітом
}

\author{
I. М. Шевчук ${ }^{1}$, С. С. Сніжко ${ }^{1}$, С. А. Андреєщев ${ }^{2}$ \\ ${ }^{1}$ Івано-Франківський національний медичний університет, \\ ${ }^{2}$ Національна медична академія післядипломної освіти імені П. Л. Шупика, м. Київ

\section{Surgical treatment of patients, suffering esophageal perforation, complicated by an acute purulent mediastinitis}

\author{
I. M. Shevchuk ${ }^{1}$, S. S. Snizhko', S. A. Andreieshchev ${ }^{2}$ \\ ${ }^{1}$ Ivano-Frankivsk National Medical University, \\ ${ }^{2}$ Shupyk National Medical Academy of Postgraduate Education, Kyiv
}

\begin{abstract}
Реферат
Мета. Покращити результати лікування хворих з перфорацією стравоходу (ПС), ускладненою гострим гнійним медіастинітом (ГГМ).

Матеріали і методи. Упродовж 2004 - 2018 рр. у відділенні торакальної хірургії Івано-Франківської обласної клінічної лікарні оперовано 30 хворих з ПС, ускладненою ГГМ. Вік хворих коливався від 21 до 76 років, у середньому становив $(36,3 \pm 3,9)$ року. Чоловіків було 21 (70\%), жінок - 9 (30\%).

Результати. Інтрамедіастинальне введення антибактеріальних препаратів та зрошення швів стравоходу сприяли швидкій ліквідації гнійно-запального процесу в середостінні. Повністю герметичні шви перфорованої ділянки стравоходу констатували у 6 (37,5\%), зменшення розмірів дефекту стінки стравоходу - у 9 (56,2\%) із 16 хворих.

Висновки. ПС слід зашивати для відмежування просвіту стравоходу від клітковини середостіння, локалізації гнійного процесу у середостінні і стабілізації загального стану хворого. Мініінвазивні оперативні втручання за допомогою відеоасистованої торакоскопії можуть слугувати операціями вибору у хворих з ПС та поширеним ГГМ для санації і дренування гнійно-запальних вогнищ у середостінні, стабілізації стану хворих та попередження розвитку септичних ускладнень. Інтрамедіастинальне введення антибактеріальних препаратів та зрошення швів стравоходу дають змогу покращити результати лікування, знизити ендогенну інтоксикацію (ЕI), прискорити загоєння ПС та ліквідувати гнійний процес у середостінні.

Ключові слова: перфорація стравоходу; медіастиніт; лікування перфорації стравоходу.

Abstract

Objective. To improve the treatment results in patients with esophageal perforation (EP), complicated by an acute purulent mediastinitis (APM).

Materials and methods. Through $2004-2018$ yrs in the Department of Thoracic Surgery of the Ivano-Frankivsk Regional Clinical Hospital 30 patients with EP, complicated by an APM, were operated. The patients have aged $21-76 \mathrm{yrs}$ old, and at average $-(36.3 \pm 3.9)$ yrs. There were $21(70 \%)$ men and $9(30 \%)$ women.

Results. Intramediastinal injection of antibacterial preparations and irrigation of esophageal sutures have promoted a rapid elimination of purulent-inflammatory process in mediastinum. In $6(37.5 \%)$ patients a completely hermetic sutures of the esophageal perforation site were registered, while reduction of the esophageal defect size - in $9(56.2 \%)$ of 16 patients.

Conclusion. EP must be sutured for bordering of esophageal lumen from the mediastinal cellular tissue, the mediastinal purulent process restriction and stabilization of the patient' general condition. Miniinvasive operative interventions, using video-assisted thoracoscopy, may serve the procedures of choice in patients with EP and extended APM for sanation and drainage of purulent-inflammatory foci in mediastinum, the patients' state stabilization and prevention of the septic complications development. Intramediastinal injection of antibacterial preparations and irrigation of esophageal sutures have improved the treatment results and promoted the endogenous intoxication lowering, the EP healing acceleration and to eliminate a purulent mediastinitis.

Keywords: esophageal perforation; mediastinitis; treatment of esophageal perforation.
\end{abstract}

Перфорація стравоходу (ПС) призводить до розвитку ГГМ у 67 - 84\% хворих [1]. У структурі причин ПС частка ятрогенних пошкоджень становить 52,5 - 80,6\% [1, 2]. Найбільш часто ПС діагностують під час бужування стравоходу після хімічних опіків - у 1 - 30\% хворих. Під час пневмокардіодилатації ахалазії кардії ПС виникають у 0,2 - 11\%, видалення сторонніх тіл - у 0,22 - 9,35\%, ендоскопічного склерозування варикозно розширених вен стравоходу - у 1 - 6\%, стентування неоперабельних пухлин стравоходу - у $7-11 \%$ хворих [3]. За останні роки почас- тішали спостереження спонтанного розриву стравоходу (синдрому Бурхаве) [2, 4].

Уже через 6 год після ПС під час гістологічного дослідження у стінці стравоходу виявляють гнійну інфільтрацію всіх шарів на фоні численних крововиливів [1, 4]; через добу краї дефекту мають сірий колір, коли натиснути на рану, з неї виділяється гній, а гістологічна картина характеризується різким повнокров'ям та дифузною інфільтрацією тканин нейтрофільними лейкоцитами [5]; через 12 - 24 год наявна розгорнута клінічна картина ГГМ і сеп- 
сису [6]. ПС, ускладнена ГГМ, стає причиною смерті, за даними різних авторів, від 17 до 80\% хворих [1, 3-5].

ГГМ вважають однією із найбільш складних форм хірургічної інфекції [4]. Тяжкість перебігу ГГм обумовлена наявністю в середостінні центральних симпатичних та парасимпатичних нервів, важливих кровоносних та лімфатичних судин. Клітковина середостіння також інтенсивно всмоктує продукти розпаду тканин, що прискорює розвиток тяжкої інтоксикації $[1,4]$. Сепсис діагностують у 45 100\% таких хворих, синдром поліорганної недостатності (СПОН - у $9-17 \%$ [6]. Ряд авторів звертають увагу на погане кровопостачання гнійної клітковини середостіння, що призводить до недостатньої ефективності антибактеріальної терапії у вогнищі інфекції [2].

Досі немає єдиної тактики хірургічного лікування ПС, ускладненої ГГМ [7]. Через тяжку EI, порушення гемостазу, поліорганну дисфункцію доводиться обмежувати об'єм оперативного втручання. Виходячи з цього, одні дослідники рекомендують виконувати лише дренування гнійного вогнища та плевральної порожнини [8], інші - доповнювати дренування клітковини середостіння в ділянці ПС «виключенням» стравоходу з травлення шляхом накладання езофагостоми на шиї та лігатурного виключення стравоходу на рівні стравохідно-кардіального переходу з накладанням гастростоми [2]. Є повідомлення про обнадійливі результати зашивання рани стравоходу незалежно від строків перфорації [9]. Натомість ряд авторів, вважаючи, що за наявності ГГМ зашивання рани стравоходу не має сенсу через «запрограмовану» неспроможність швів, прихильно ставиться до виконання радикального оперативного втручання - резекції стравоходу [10].

Наведене спонукає науковців до пошуку нових методів лікування, які б забезпечували максимально ефективну антибактеріальну дію у гнійній клітковині середостіння, постійне видалення гнійних мас та достатнє дренування і санацію уражених ділянок.

Мета дослідження: покращити результати лікування хворих з ПС, ускладненою ГГМ.

\section{Матеріали і методи дослідження}

Упродовж 2004 - 2018 рр. у відділенні торакальної хірургії Івано-Франківської обласної клінічної лікарні нами обстежено і оперовано 30 хворих з ПС та ГГМ. Вік хворих коливався від 21 до 76 років, у середньому становив (36,3 $\pm 3,9)$ року. Чоловіків було 21 (70\%), жінок - 9 (30\%).

Із 30 хворих у 12 (40\%) причиною ПС було пошкодження сторонніми тілами стінки стравоходу. У 7 (58,3\%) хворих ПС локалізувалась у зоні другого анатомічного звуження, у 3 (25,0\%) - в нижньому відділі стравоходу, у 2 (16,7\%) - в шийному відділі. Травму спричиняли переважно риб'ячі, курячі кістки, голки, колючі предмети. Від моменту попадання стороннього тіла в стравохід до моменту госпіталізації минало від декількох годин до 4 діб, у середньому $(1,14 \pm 0,4)$ доби. Обмежений ГГМ діагностували у 10 (83,3\%) хворих, із них у 6 - задній, у 4 - верхній. У 2 (16,7\%) хворих поширення гнійного процесу у вигляді флегмони призвело до розвитку тотального ГГМ. Обмежений ГГм локалізувався у місці перфорації, розміри його були різні і залежали від часу, що минув від моменту перфорації. У всіх 5 пацієнтів, госпіталізованих у строки до 1 доби від моменту ПС, був обмежений ГГМ. На 2-гу добу госпіталізовано 4 хворих: обмежений ГГМ діагностовано у 3 , тотальний - у 1 . На 3-ю добу госпіталізовано 3 хворих: обмежений ГГм діагностовано у 2 , тотальний - у 1 .

Другою за частотою причиною ПС із розвитком ГГМ був спонтанний розрив стравоходу, або синдром Бурхаве, який діагностували у 11 (36,7\%) хворих. У всіх хворих розрив стінки стався в нижній третині стравоходу: у 7 (63,6\%) - справа, у 4 (36,4\%) - зліва. Синдром Бурхаве діагностували у 8 (72,7\%) хворих у стані алкогольного сп'яніння. Довжина розривів стінки стравоходу коливалася від 2 до 9 см. Із 11 хворих у 8 (72,7\%) спостерігали задній ГГМ, у $3(27,2 \%)$ - тотальний. У 6 (54,5\%) хворих із синдромом Бурхаве разом із ПС стався розрив медіастинальної плеври з розвитком піопневмотораксу. Саме у разі розриву вісцеральної плеври виникав обмежений ГГМ, оскільки відбувалось звільнення гнійного вмісту із середостіння у плевральну порожнину.

Ятрогенні ПС з розвитком ГГМ діагностували у 7 (23,3\%) хворих. Основними причинами ятрогенних ПС були: видалення стороннього тіла стравоходу - у 3 (42,9\%) хворих, бужування рубцево звуженого стравоходу після хімічного опіку ригідними бужами всліпу - у 2 (28,6\%), проведення діагностичної езофагогастродуоденоскопії (ЕГДС) - у 1 (14,3\%), ендопротезування пухлини середньої третини стравоходу - у 1 (14,3\%) хворого. У всіх хворих з ятрогенними ПС діагностували обмежений ГГМ, що було обумовлено своєчасними діагностикою ПС та відповідним хірургічним лікуванням.

3 метою аналізу ефективності та результатів застосування запропонованих нами методів хірургічного лікування всіх хворих ми розподілили на дві групи: 1-ша група (основна) - 16 (53,3\%) хворих, у яких застосовували розроблену нами тактику хірургічного лікування, що включала інтрамедіастинальне введення антибактеріальних препаратів та зрошення швів місця перфорації стравоходу з постійною санацією навколишньої клітковини середостіння; 2-га група (контрольна) - 14 (46,7\%) хворих, у яких застосовували стандартні методи лікування.

\section{Результати}

У разі інтрамедіастинального введення антибактеріальні препарати вже за одну годину поширювалися на всі відділи середостіння (Пат. на корисну модель № 105664). Суть даного методу: над яремною вирізкою виконували пункцію передньо-верхнього середостіння за В. І. Казанським, за допомогою набору для пункції підключичної вени за методикою Сельдінгера у середостіння вводили катетер, який підключали до крапельної системи. Після цього хворим у післяопераційному періоді в середостіння вводили розчини антибіотиків (левофлоксацин 500 мг, цефтриаксон 1,0 г) та антисептиків (декасан) краплинно зі швидкістю 60 крапель за 1 хв протягом 2 год, чергуючи розчини антибіотиків та антисептиків.

Методика місцевого зрошення швів місия перфорацї стравоходу з постійною санацією навколишнъої клітковини середостіння. Після зашивання перфорованої стінки стравоходу вздовж швів на всій протяжності розміщу- 
вали поліхлорвініловий катетер від крапельної системи 3 множинними перфорованими отворами. Катетер виводили через плевральну порожнину та грудну стінку по найкоротшому шляху назовні і через нього в післяопераційному періоді вводили краплинно розчини антисептиків (декасан, хлоргексидин) зі швидкістю 40 - 60 крапель за 1 хв протягом 3 - 4 год вранці та ввечері, об'єм введених антисептичних розчинів становив $2-3$ л на добу. Тобто відбувалося постійне зрошення швів анастомоза та навколишніх тканин середостіння антисептичними розчинами, механічне вимивання і видалення гнійних мас. До місця перфорації підводили товстий дренаж для забезпечення активної аспірації промивних розчинів.

Тактика хірургічного лікування хворих з первинним ГГМ залежала від причини, локалізації, поширеності гнійного процесу в середостінні та часу, що минав від початку захворювання до госпіталізації у спеціалізований стаціонар. Вибір тактики хірургічного лікування ПС в умовах ГГМ є вирішальним у досягненні успішного результату.

Усі хворі з ПС, ускладненою ГГМ, були оперовані. Для визначення хірургічного доступу та об'єму операції враховували місце ПС, стан стінки перфорованої частини стравоходу, характер ГГМ (обмежений чи тотальний), локалізацію і форму ГГМ та наявність ускладнень.

Показаннями до бокової торакотомії, медіастинотомії, зашивання перфоративного отвору стравоходу з активним дренуванням середостіння та плевральної порожнини 3 - 4 дренажами були: ранні строки від початку захворювання за відсутності гнійного розплавлення стінки стравоходу і наявності технічної можливості ушивання ПС; обмежений ГГМ; тотальний ГГМ за необхідності повної візуалізації всіх відділів середостіння.

У хворих, госпіталізованих у строки до 1 доби від початку захворювання, виконували бокову торакотомію в залежності від місця ПС, медіастинотомію над ураженою ділянкою середостіння, видаляли некротичні і гнійні маси, мобілізували пошкоджену ділянку стравоходу, максимально розкриваючи всі уражені ділянки середостіння під контролем зору з детальною ревізією всіх відділів середостіння. Уражену ділянку стравоходу зашивали двохрядним швом, захоплюючи слизову і м'язову оболонки. Хворим основної групи до місця швів стравоходу підводили катетер для зрошення і постійного видалення гнійних мас та використовували інтрамедіастинальне введення антибактеріальних препаратів. Операцію завершували введенням трьох дренажів: одного - до місця перфорації стравоходу для відведення розчинів антисептиків та гною безпосередньо від місця ПС, другого - у задній синус плевральної порожнини, третього (повітряного) - до верхівки легенів. Усі дренажі під'єднували до активної аспіраційної системи з метою створення негативного тиску у плевральній порожнині та активного відведення гнійного вмісту. Негативний тиск має важливе значення для швидкого розправлення легені і відповідно локалізації гнійного процесу в плевральній порожнині. Дану хірургічну тактику використали у 7 (43,8\%) хворих основної групи та у 6 (42,9\%) - контрольної.

Широкий доступ із використанням торакотомії у хворих з тотальним ГГМ необхідний для детальної візуаліза- ції всіх відділів середостіння з тим, щоб розкрити всі уражені ділянки медіастинальної плеври та видалити некротичні тканини і гнійні маси. Дискутабельним залишається питання зашивання ПС. Виходячи з власного досвіду, ми вважаємо зашивання ПС не показаним у разі гнійного розплавлення стінки стравоходу в умовах тотального ГГМ у пізно госпіталізованих хворих. У інших хворих зашивання ПС є доцільним і виправданим. У 10 (76,9\%) хворих ми зашили ПС двохрядним вузловим швом нитками вікрил 3,0 чи дексон II. Неспроможність швів виникла у 7 (70\%) хворих, проте розмір перфоративного отвору стравоходу зменшився, за даними контрастної езофагографіï, у 6 (85,7\%) хворих, що полегшило перебіг захворювання, зменшило строки загоєння перфорації та покращило прогноз. Навіть у разі виникнення неспроможності швів у ділянці ПС відмежування просвіту стравоходу від клітковини середостіння хоч на $2-3$ дні є запорукою запобігання його повторному інфікуванню, локалізації гнійного процесу в середостінні без поширення гнійної інфекції, стабілізації загального стану хворого за рахунок зменшення ознак гнійної інтоксикації.

Помер 1 хворий контрольної групи. Причинами смерті були септичний шок та СПОН.

У ранньому періоді після таких операцій хворим призначали парентеральне харчування та через назогастральний зонд, яке з другого тижня доповнювали частковим ентеральним харчуванням за відсутності стравохідноплевральної нориці.

Бокову торакотомію, медіастинотомію та дренування середостіння як «операцію відчаю» виконали 2 (14,3\%) хворим контрольної групи з тотальним ГГМ і СПОН та вкрай тяжким станом. Обидва хворі померли. Виконання додаткових операцій з метою «виключення» стравоходу було неможливим через критичний стан пацієнтів.

Бокову торакотомію, зашивання ПС та накладання езофагостоми і гастростоми за Кадером виконали 2 (14,3\%) хворим контрольної групи. Обидва хворі померли. У 1 хворого причиною ПС був синдром Бурхаве, у 1 - неспроможність швів езофагоентероанастомоза, яку діагностували на 3-й день після операції Льюїса на фоні тотального ГГМ. На нашу думку, розширення обсягу оперативного втручання з метою накладання гастростоми чи єюностоми не завжди є виправданим, адже супроводжується додатковою травмою, збільшує анестезіологічний ризик, що може створити пряму загрозу для життя хворого.

Бокову торакотомію, медіастинотомію, зашивання ПС та накладання гастростоми за Кадером виконали 2 (14,3\%) хворим контрольної групи. Помер 1 хворий. Причиною смерті стали тотальний ГГМ, піопневмоторакс, сепсис та $\mathrm{C \Pi OH}$.

Цервікотомію за Разумовським, медіастинотомію, розкриття верхнього середостіння, зашивання ПС та дренування плевральної порожнини 2 - 3 дренажами за Бюлау виконали 2 (14,3\%) хворим контрольної групи. Обидва хворі одужали. У цих хворих був ГГМ, який поширювався лише в межах верхнього середостіння і не супроводжувався ознаками сепсису чи СПОН.

Нагноєння післяопераційної рани виникло у 6 (31,6\%) iз 19 хворих, яким виконали бокову торакотомію. 
Відеоасистовану торакоскопію (ВАТС) застосували у 9 (56,2\%) хворих основної групи.

Перевагами ВАТС вважаємо мінімальну операційну травму, скорочення тривалості операції. Особливої актуальності ці переваги ВАТС набувають щодо хворих у тяжкому стані, яким оперативне втручання виконують в умовах ГГМ і сепсису. Також перевагою ВАТС є мінімізація проблеми нагноєння післяопераційної рани в місцях накладання портів. Під час ВАТС у стислий термін $(20-40$ хв) можна виконати ефективне дренування параезофагеальної і медіастинальної клітковини та плевральної порожнини.

Показаннями до виконання ВАТС вважаємо поширене гнійне ураження клітковини середостіння з гнійним розплавленням стінки стравоходу, дефекти його стінки протяжністю більше 7 см, прогнозовану неспроможність швів стравоходу в умовах тотального ГГМ за наявності СПОН у хворих з V ступенем анестезіологічного ризику. Застосування ВАТС виправдане у хворих з ПС, ускладненою обмеженим ГГм, а також у разі піопневмотораксу чи емпієми плеври.

Виконуючи ВАТС, обов'язково застосовували дренування плевральної порожнини 2 - 3 дренажами за Бюлау, що давало змогу локалізувати гнійний процес у середостінні $і$ плевральній порожнині, досягнути швидкого розправлення колабованої легені, стабілізувати стан хворого. За цих умов на 3 - 4-му тиж після операції формувалася стравохідно-плевральна нориця, яка через 3 - 4 тиж самостійно заживала. Зашивання функціонуючої стравохідно-плевральної нориці показане за повної ліквідації запального процесу в середостінні і плевральній порожнині після 4 тиж від моменту ПС з використанням бокової торакотомії. У всіх хворих, щодо яких застосовували хірургічну тактику, що передбачала ВАТС, використовували інтрамедіастинальне введення антибактеріальних препаратів.

Таким чином, в основній групі хворих хірургічне лікування включало торакотомію, медіастинотомію, зашивання ПС з дренуванням середостіння та ВАТС з використанням інтрамедіастинального введення антибактеріальних препаратів та місцевого зрошення швів стравоходу.

Для оцінки ефективності лікування ми дослідили динаміку строків загоєння рани стравоходу за даними контрастного рентгенобстеження стравоходу та ЕГДС, показникми EI, а саме лейкоцитарним індексом інтоксикації (ЛІІ), та тяжкості ендотоксикозу за шкалою АРАСНЕ II в модифікації А. П. Радзіховського, застосування якої не потребує аналізу додаткових лабораторних даних та показників газів крові, що не завжди можливо в стаціонарі.

В основній групі хворих вже на 1-шу добу після операції ЛІІ знизився майже втричі (3 6,2 до 2,1 у.о.) та нормалізувався на 5-ту добу. У контрольній групі ЛІІ на 1-шу добу після операції знизився з 6,1 до 3,2 у.о. і був підвищеним на 5-ту добу, залишаючись на рівні 2,6 у.о.

Подібну картину спостерігали і в разі оцінки тяжкості ендотоксикозу за модифікованою шкалою АРАСНЕ II. Так, до операції в основній групі індекс ЕІ дорівнював 17,3 1,6, на 1-шу добу зафіксували його зниження до 9,4 \pm 0,8 та нормалізацію на 5-ту добу. У контрольній групі до операції індекс ЕІ дорівнював 18,9 $\pm 2,0$, на 1-шу добу після операції він знизився до 14,7 £ 1,2, на 5-ту добу - до 10,6 \pm 0,7, що свідчило про продовження гнійно-запального процесу в клітковині середостіння.

Динаміка показників ЕI у хворих основної групи свідчить про значно швидше стихання гнійно-запального процесу в середостінні у разі застосування інтрамедіастинального введення антибактеріальних препаратів та місцевого зрошення швів стравоходу.

Контрольне проведення ЕГДС та рентгенконтрастного обстеження стравоходу показало, що вже на 7 - 8-му добу після операції повністю герметичні шви перфорованої ділянки стравоходу були у 6 (37,5\%) хворих основної групи, розміри дефекту стінки стравоходу зменшилися у 9 (56,2\%) хворих, на 14-ту добу - у 12 (75\%) та 3 (18,8\%) хворих відповідно.

На 7 - 8-му добу після операції повністю герметичні шви перфорованої ділянки стравоходу констатували у 2 $(14,3 \%)$ хворих контрольної групи, зменшення розмірів дефекту стінки стравоходу - у 3 (21,4\%) хворих, на 14-ту добу - у 4 (28,6\%) та 5 (35,7\%) хворих відповідно.

У 1 хворого основної групи спостерігали розвиток гнійно-некротичного процесу із швидким поширенням у всі відділи середостіння, сепсисом, наростанням поліорганної та серцево-судинної недостатності. Активна хірургічна тактика та інтенсивна інфузійна терапія не мали успіху, хворий помер на 3-тю добу від початку захворювання. Отже, летальність в основній групі хворих становила 6,2\%. Решту 15 хворих виписали із стаціонару в задовільному стані в середньому через $(21 \pm 3,4)$ дня. В контрольній групі померли 6 (42,9\%) хворих. Причинами смерті були пізне звернення за медичною допомогою, рефрактерний септичний шок, наростаюча поліорганна та серцево-судинна недостатність. Середня тривалість лікування у стаціонарі хворих контрольної групи становила (29 $\pm 3,1)$ ліжко-дня.

\section{Обговорення}

Основними методами хірургічного лікування хворих основної групи були торакотомія з медіастинотомією, зашивання ПС і дренування середостіння та ВАТС із використанням інтрамедіастинального введення антибактеріальних препаратів та місцевого зрошення швів стравоходу. Зашивання перфоративного отвору стравоходу, яке дає змогу зменшити частоту повторного інфікування клітковини середостіння, розміри ПС або повністю ліквідувати пошкодження, вважаємо необхідним у всіх хворих, за винятком тих, у кого виявляють гнійне розплавлення стінки стравоходу. Для санації і постійного відведення гнійних мас від місця ПС слід застосовувати місцеве зрошення швів стравоходу у всіх спостереженнях, що значно покращує результати лікування ПС та знижує показники ЕI. Наш невеликий досвід застосування ВАТС у хворих з ПС, ускладненою ГГМ, дає підстави констатувати, що цей метод має безсумнівні пріоритети перед торакотомією. У ряду хворих із встановленим діагнозом ПС, ускладненої ГГМ, ВАТС може забезпечити достатній радикалізм втручання за мінімальної травматичності.

В діагностично складних ситуаціях ВАТС має стати методом вибору для остаточного визначення тактики хірургічного лікування. 


\section{Висновки}

1. Вибір хірургічної тактики повинен буди індивідуальний у кожного окремого хворого з ПС. Основною метою хірургічного лікування є ліквідація гнійно-запального процесу в середостінні та стабілізація стану хворих.

2. Розширені операції з приводу ПС, ускладненої ГГМ, супроводжуються високою післяопераційною летальністю, що обмежує іх використання у хворих із сепсисом та СПОН.

3. Перфоративний отвір стравоходу слід зашивати для відмежування просвіту стравоходу від клітковини середостіння, локалізації гнійного процесу в середостінні і стабілізації загального стану хворого.

4. Мініінвазивні оперативні втручання за допомогою BATC можуть слугувати операціями вибору у хворих 3 ПС та поширеним ГГМ для санації і дренування гнійнозапальних вогнищ у середостінні, стабілізації стану хворих та попередження розвитку септичних ускладнень.

5. Інтрамедіастинальне введення антибактеріальних препаратів та місцеве зрошення швів стравоходу дають змогу покращити результати лікування, знизити ЕI, прискорити загоєння ПС, ліквідувати гнійний процес у середостінні.

\section{References}

1. Canbay G, Bertrand X. Mediastinitis on oesphagal perforation. Rev Med Liege. 2017 Mar;72(3):121-125. PMID: 28387488. [In French].

2. Karagyozov P, Minchev T, Tishkov I, Plachkov I. Hybrid therapy of late diagnosed esophageal perforation, complicated by mediastinitis and bilateral empyema. Endoscopy. 2017 Feb;49 (S 01):E127-E128. doi: $10.1055 / \mathrm{s}-0043-103947$.

3. Park IH, Lim HK, Song SW, Lee KH. Perforation of esophagus and subsequent mediastinitis following mussel shell ingestion. J Thorac Dis. 2016 Aug;8(8):E693-7. doi: 10.21037/jtd.2016.07.88.

4. Nakano T, Onodera K, Ichikawa H, Kamei T, Taniyama Y, Sakurai T, Miyata G. Thoracoscopic primary repair with mediastinal drainage is a viable option for patients with Boerhaave's syndrome. J Thorac Dis. 2018 Feb;10(2):784-789. doi: 10.21037/jtd.2018.01.50.

5. Soppimath SS, Chiniwalar S, Hartimath B, Padasali P. Endoscopic mediastinal debridement for mediastinitis resulting from upper esophageal perforation. Endoscopy. 2016;48 Suppl 1 UCTN:E168-9. doi: 10.1055/ s-0042-105562. Epub 2016 Apr 29.

6. Shevchuk IM, Snizhko SS. Analiz uskladnen gostroho gniynogo mediastunitu. Klin khir. 2017 Sich. (1):36-8. [In Ukrainian].

7. Krüger M, Decker S, Schneider JP, Haverich A, Schega O. Surgical treatment of acute mediastinitis. Chirurg. 2016 Jun;87(6):478-85. doi: 10.1007/s00104-016-0171-8. [In German].

8. Nirula R. Esophageal perforation. Surg Clin North Am. 2014 Feb;94(1):35-41. doi: 10.1016/j.suc.2013.10.003.

9. Markar SR, Mackenzie H, Wiggins T, Askari A, Faiz O, Zaninotto G, Hanna GB. Management and Outcomes of Esophageal Perforation: A National Study of 2,564 Patients in England. Am J Gastroenterol. 2015 Nov;110(11):1559-66. doi: 10.1038/ajg.2015.304.

10. Kim JE, Ryoo SM, Kim YJ, Lee JS, Ahn S, Seo DW, Sohn CH, Ryu JM, Kim WY. Incidence and Clinical Features of Esophageal Perforation Caused by Ingested Foreign Body. Korean J Gastroenterol. 2015 Nov;66(5):255-60. doi: 10.4166/kjg.2015.66.5.255. 